\title{
ANALISA BIAYA PRODUKSI DENGAN MEMBANDINGKAN BIAYA STANDAR DAN BIAYA AKTUAL PADA PT TIRTA MAMBERAMO SORONG
}

\author{
Markus Muda, SE \\ Akuntansi Keuangan Publik \\ Program Studi Diploma IV Akuntansi \\ Politeknik Katolik Saint Paul Sorong \\ markusmuda@gmail.com
}

\begin{abstract}
Abstrak
Biaya standar merupakan salah satu alat pengendalian biaya yang diterapkan terlebih dahulu untuk membantu manajer didalam menilai suatu kebijaksanaan khususnya dibagian produksi. Dalam menentukan besarnya biaya standar diperlukan berbagai faktor yang dapat mempengaruhi proses produksi. Akan tetapi didalam pelaksanaannya seringkali terjadi penyimpangan antara standar yang telah ditetapkan dengan sesungguhnya, sebagaimana yang terjadi pada PT TirtaMamberamo Sorong. Perusahaan sebelum melaksanakan produksi telah menetapkan standar, baik itu unit produksi maupun yang dihasilkan terhadap biaya yang aan dikeluaran. Namun dalam kenyataannya biaya yang sesungguhnya terjadi lebih besar dari biaya yang distandarkan. Untuk itu melalui penelitian ini ingin diketahui faktor penyebab terjadinya selisih merugikan antara biaya produksi standard an biaya produksi sesungguhnya.
\end{abstract}

Kata Kunci : Biaya Standar, Biaya Produksi

\begin{abstract}
Standard cost is one of the tools of controlling the cost that assigned before for help the manager to evaluate the policy, especially in the production. In determining the standard cost we need many factors that can influence production process. But in its implementation sometimes there are irregularities between standard costing applied with the actual cost, as happened in PT. Tirta Memberamo Sorong. Before the company does the production they have set the standardization, both in the unit production nor the resulting for the cost to be incurred. But in the fact actual cost is bigger than standard cost. So, the purposes of the research the researcher want to know the causative factors about the difference in loss between standard cost and actual cost.
\end{abstract}

Keywords: Standar Cost, Production Cost 


\section{PENDAHULUAN}

\section{Latar Belakang}

PT Tirta Mamberamo Sorong merupakan salah satu perusahaan yang produksinya bersifat massa, artinya aktivitas perusahaan tersebut rutin dan berulang ulang. Dalam menentukan harga pokok produksi, perusahaan menggunakan harga pokok standar. Sehingga bahan yang diperlukan, tenaga yang digunakan maupun biaya overhead pabrik, disiapkan sebelum proses produksi dilaksanakan. Adapun biaya standar yang digunakan yaitu berdasarkan pengalaman masa lalu. Selama ini biaya standar yang ditetapkan belum dapat ditetapkan sepenuhnya oleh perusahaan sehingga timbul selisih biaya produksi standar dengan biaya produksi aktual.

\section{Rumusan Masalah}

Berdasarkan latar belakang masalah, maka masalah yang menjadi pokok pembahasan adalah :

Membandingkan biaya standar dan biaya aktual serta dampaknya terhadap biaya produksi. Proses analisis selisih menggunakan metode dua selisih untuk perhitungan biaya bahan baku dan tenaga kerja langsung, serta menggunakan metode dua selisih untuk perhitungan biaya overhead pabrik.

\section{Tujuan Penelitian}

Untuk mengetahui apakah terjadi selisih antara biaya standar dan biaya produksi aktual.Untuk mengetahui factor-faktor apa saja yang menyebabkan terjadinya selisih biaya produksi standar dan biaya produksi aktual.Untuk mengetahui selisih-selisih tersebut menguntungkan atau merugikan perusahaan.

\section{TINJAUAN PUSTAKA}

Objek kegiatan akuntansi adalah keuangan yang menyangkut biaya. Dalam prinsip akuntansi Indonesia (PAI), biaya adalah "pengorbanan yang dilakukan untuk memperoleh barang atau jasa yang diukur dengan nilai uang, baik itu pengeluaran berupa uang, melalui tukar menukar atau melalui pemberian jasa".

Menurut Mulyadi, "Biaya adalah pengorbanan sumber ekonomi, yang diukur dalam satuan uang, yang telah terjadi atau kemungkinan akan terjadi untuk tujuan tertentu"

Biaya produksi merupakan hal penting dalam mengolah suatu produk, beberapa. Menurut Supriyono "Biaya produksi adalah semua biaya yang berhubungan dengan fungsi produksi atau kegiatan pengolahan bahan baku menjadi produk selesai, biaya produksi dapat digolongkan kedalam: (1) Biaya bahan Baku; (2) Biaya Tenaga Kerja Langsung; (3) Biaya Overhead Pabrik"

Menurut Matz dan Usry. biaya standar adalah "biaya yang ditetapkan terlebih dahulu untuk memproduksi satu unit atau sejumlah unit produk selama periode tertentu dimasa mendatang"

Pada umumnya suatu perusahaan sebelum memulai kegiatan produksinya, terlebih dahulu menyusun standar (budged) secara menyeluruh. Dalam menyusun standar (budged) telah dilakukan analisa dan berbagai pertimbangan terhadap semua factor yang mempengaruhi proses produksi dimasa yang akan datang. Walaupun demikian bukan jaminan dalam pelaksanaannya dapat sesuai dengan apa yang sesungguhnya terjadi. Sebab dalam proses produksi akan dipengaruhi oleh situasi dan kondisi perusahaan pada saat proses produksi berlangsung sehingga sering terjadi penyimpanganpenyimpangan terhadap anggaran dan juga kepada standar yang telah disusun oleh perusahaan.

Menurut Mas'ud, penyimpangan atau selisih diberikan batasan sebagai berikut: "Selisih adalah perbedaan antara biaya menurut standar (budged) dengan biaya sesungguhnya yang terjadi, sebab-sebab terjadinya selisih tersebut bagi manajemen perlu diketahui dengan menganalisa selisih yang terjadi, karena selisih merupakan petunjuk adanya ketidak efisiensinya, ketidaktepatannya pelaksanaan atau sebaliknya tidak tepat standar"

\section{METODE PENELITIAN}

\section{Teknik dan Metode Pengumpulan Data}

Jenis data yang digunakan dalam penelitian ini adalah data kuantitatif, yaitu data yang berbentuk angka yang dapat dihitung secara pasti seperti jumlah bahan baku yang digunakan, harga bahan baku, tingkat upah tenaga kerja langsung dan jumlah tenaga kerja yang digunakan serta biaya overhead pabrik yang digunakan.

Adapun sumber data yang digunakan dalam penelitian ini adalah data primer, yaitu data yang diperoleh secara langsung dari tempat penelitian. Data tersebut mengenai jumlah produksi air minum dalam kemasan, biaya produksi standard an biaya produksi aktual yang dkeluarkan oleh perusahaan yang berhubungan dengan proses produksi pada tahun 2015.

Teknik pengumpulan data yang digunakan dalam penelitian ini adalah : 
Wawancara

Wawancara yaitu melakukan Tanya jawab secara langsung dengan karyawan yang diberi wewenang dan berpedoman pada daftar pertanyaan yang telah disiapkan sebelumnya.

Observasi

Observasi yaitu mengadakan pengamatan langsung terhadap perusahaan yang dijadikan objek penelitian dengan maksud untuk memperoleh masukan dan melihat langsung kegiatan perusahaan terutama yang berkaitan dengan proses produksi.

\section{Variabel Penelitian}

Dalam penelitian ini, variabel yang mempengaruhi( independen ) yaitu biaya standar dan biaya aktual pada perusahaan PT Tirta Mamberamo Sorong.

Dalam penelitian ini variabel yang dipengaruhi (dependen) yaitu biaya produksi pada PT Tirta Mamberamo Sorong

\section{PEMBAHASAN DAN HASIL}

\section{Penyajian Data}

\section{Elemen-elemen Biaya Produksi Biaya Bahan Baku}

Biaya bahan baku adalah biaya perolehan biaya bahan baku yang dipergunakan dalam memperhitungkan harga per-unit bahan tersebut.

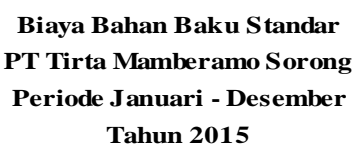

\begin{tabular}{|c|c|c|c|c|c|c|c|c|}
\hline No & Keterangan & Tota & iaya Bahan & $\begin{array}{r}\text { Perse } \\
\text { ntase }\end{array}$ & \multicolumn{2}{|c|}{ Biaya/Bulan } & \multicolumn{2}{|c|}{ Biaya/Tahun } \\
\hline 1. & $\begin{array}{l}\text { Departemen Percampuran } \\
\text { - Air } \\
\text { - Beberapa campuran } \\
\quad \text { Penetralis ir Air }\end{array}$ & $\mathrm{Rp}$ & $13,000,000$ & $50 \%$ & $\begin{array}{l}\mathrm{Rp} \\
\mathrm{Rp}\end{array}$ & $\begin{array}{r}500,000 \\
6,500,000\end{array}$ & $\begin{array}{l}\mathrm{Rp} \\
\mathrm{Rp}\end{array}$ & $\begin{array}{r}6,000,000 \\
78,000,000\end{array}$ \\
\hline 2. & $\begin{array}{l}\text { Departemen Pengisian } \\
\text { - Galon } \\
\text { - Botol } \\
\text { - Kemas an Cup }\end{array}$ & $\mathrm{Rp}$ & $13,000,000$ & $30 \%$ & $\mathrm{Rp}$ & $3,900,000$ & Rp & $46,800,000$ \\
\hline 3. & $\begin{array}{l}\text { Departemen Penggulingan } \\
\text { - Kertas lebel dan Karton }\end{array}$ & $\mathrm{Rp}$ & $13,000,000$ & $20 \%$ & $\mathrm{Rp}$ & $2,600,000$ & $\mathrm{Rp}$ & $2,600,000$ \\
\hline & Total & & & $100 \%$ & $\mathbf{R p}$ & $13,500,000$ & $\mathbf{R p}$ & $3,400,000$ \\
\hline
\end{tabular}

Sumber : PT Tirta Mamberamo Sorong, 2015 


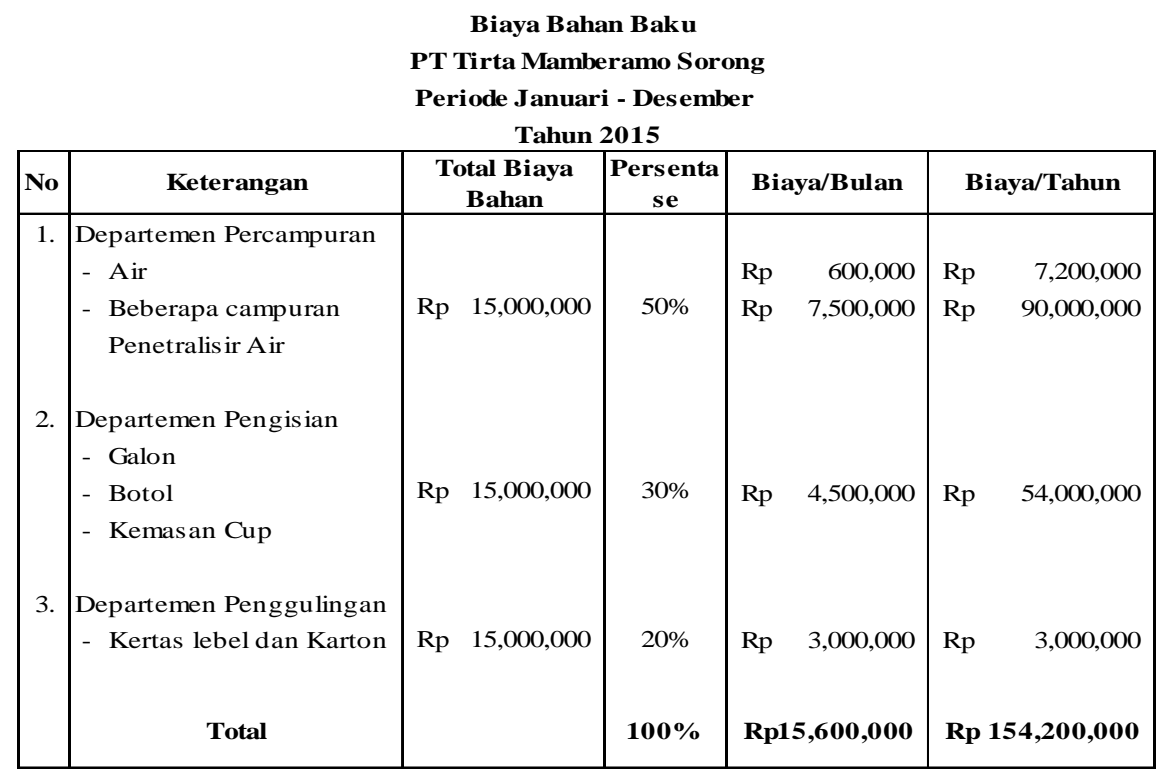

Sumber : PT Tirta Mamberamo Sorong, 2015

Berdasarkan hasil produksi pada tahun sebelumnya yaitu tahun 2014 dan dengan mempertimbangkan kemungkinan adanya kenaikan permintaan konsumen terhadap ketiga jenis produk, maka untuk tahun 2015 perusahaan menetapkan standar hasil produksi sebesar 300.000 unit ukuran $240 \mathrm{ml}$, 360.000 unit ukuran $600 \mathrm{ml}$, dan 19.440.000 untuk ukuran gallon 19 liter.

Standar jumlah pemakaian bahan baku dan standar harga bahan baku yang dikeluarkan oleh perusahaan untuk memproduksi satu unit kemasan air minum yaitu ukuran $240 \mathrm{ml}$ sebesar Rp.195.65 untuk jenis $600 \mathrm{ml}$ sebesar Rp.7.41 dan untuk jenis gallon 19 L sebesar Rp. 3.705
Untuk pemakaian biaya bahan baku aktual harga bahan baku yang dikeluarkan perusahaan untuk memproduksi satu unit kemasan air minum yaitu untuk ukuran $240 \mathrm{ml}$ sebesar Rp.22.16,- untuk ukuran $600 \mathrm{ml}$ sebesar Rp. 8.56 dan untu ukuran gallon 19 liter sebesar Rp.4.28.

Dilihat bahwa antara biaya standar yang ditetapkan dan biaya sesungguhnya yang terjadi terdapat perbedaan. Apabila dibandingkan maka akan mendapatkan selisih antara biaya produksi yang distandarkan dengan biaya produksi sesungguhnya yaitu selisih harga bahan baku yang digunakan. Adapun jenis dan jumlah bahan baku yang dibutuhkan baik standar maupun aktual selama tahun 2015 sebagai berikut :

\section{Biaya Tenaga Kerja \\ PT Tirta Mamberamo Sorong \\ Periode Januari - Desember}

Tahun 2015

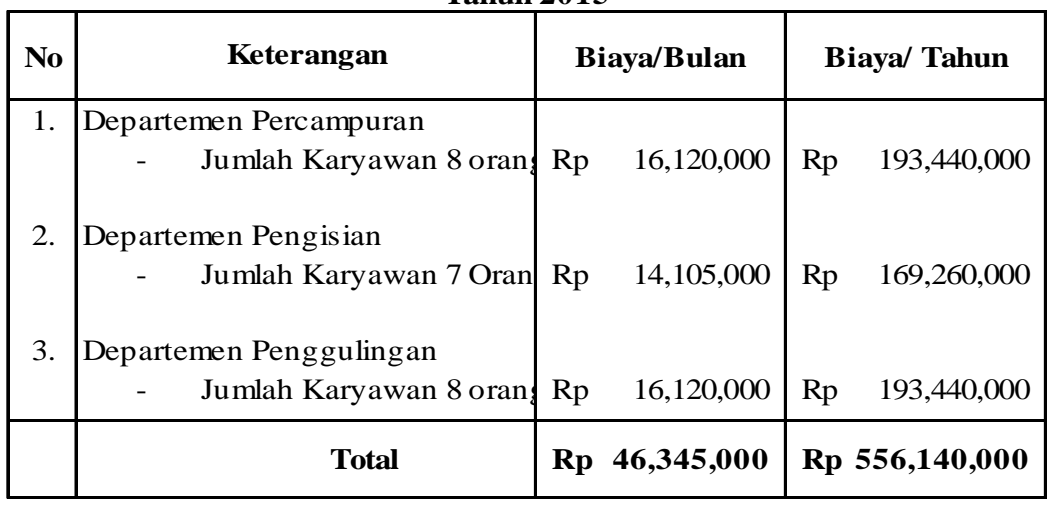

Sumber : PT Tirta Mamberamo Sorong, 2015 


\begin{tabular}{|c|c|c|c|c|c|}
\hline $\begin{array}{l}1 . \\
2 .\end{array}$ & $\begin{array}{l}\text { Departemen Percampuran } \\
\text { - Jumlah Karyawan } 8 \text { orang }\end{array}$ & $\mathrm{Rp}$ & $16,120,000$ & $\mathrm{Rp}$ & $193,440,000$ \\
\hline 2. & $\begin{array}{l}\text { Departemen Pengisian } \\
\text { - Jumlah Karyawan } 7 \text { Orang }\end{array}$ & $\mathrm{Rp}$ & $14,105,000$ & $\mathrm{Rp}$ & $169,260,000$ \\
\hline \multirow[t]{3}{*}{3.} & Departemen Penggulingan & & & & \\
\hline & - $\quad$ Jumlah Karyawan 8 orang & $\mathrm{Rp}$ & $16,120,000$ & $\mathrm{Rp}$ & $193,440,000$ \\
\hline & Total & \multicolumn{2}{|c|}{$\operatorname{Rp} 46,345,000$} & $\mathbf{R p}$ & $556,140,000$ \\
\hline
\end{tabular}

Sumber : PT Tirta Mamberamo Sorong, 2015

Jumlah tenaga kerja langsung yang ada pada bagian produksi PT Tirta Mamberamo Sorong adalah 23 orang yang terbagi dalam 3 departemen yaitu departemen percampuran 8 orang, departemen pengisian 7 orang, dan departemen penggulingan 8 orang.

Perusahaan PT Tirta Mamberamo Sorong dalam memberikan balas jasa pada karyawannya menggunakan sistem Upah Minimum Provinsi (UMP) yang terbagi dalam jumlah unit yang dihasilkan. Produksi dilakukan setiap hari, dalam satu bulan terhitung 25 hari kerja sehingga dalam setahun perusahaan beroperasi selama 300 hari kerja. Perusahaan menerapkan jam kerja 8 jam perhari mulai pukul 08.00-12.00 WIB dan 13.0017.00 WIB.
Untuk tarif upah Tenaga Kerja Langsung yang dikeluarkan perusahaan untuk setiap karyawan tidak terjadi perubahan dengan standar Biaya Tenaga Kerja Langsung. Dalam tahun 2015 jam kerja aktual atau sesungguhnya tidak melebihi jam kerja standar, menyebabkan perusahaan tidak perlu menambah pengeluaran Biaya Tenaga Kerja Laangsung, sehingga total biaya tenaga kerja langsung tidak

bertambah. Jam kerja ditahun 2015 adalah 2.400 jam dibagi dalam masing-masing ukuran.

Biaya tenaga kerja langsung diatas bahwa tidak terjadi selisih antara standar dan aktual dikarenakan upah yang diberikan sesuai dengan Upah Minimum Propinsi (UMP) setiap tahunya yaitu pada tahun 2014 sebesar Rp. 1.870.000,- dan Tahun 2015 sebesar Rp. 2.015.000.

\section{Biaya Overhead Pabrik Standar}

PT Tirta Mamberamo Sorong

Tahun 2015

\begin{tabular}{|c|c|c|c|c|c|}
\hline No & Keterangan & \multicolumn{2}{|c|}{ Biaya/Bulan } & \multicolumn{2}{|c|}{ Biaya/tahun } \\
\hline 1. & Biaya Tenaga Kerja Dep. Pembantu & & $4,010,000$ & $\mathrm{Rp}$ & $48,120,000$ \\
\hline 2. & Biaya Listrik & $\mathrm{Rp}$ & $18,000,000$ & $\mathrm{Rp}$ & $216,000,000$ \\
\hline 3. & Biaya Bahan Penolong & $\mathrm{Rp}$ & $3,500,000$ & $\mathrm{Rp}$ & $42,000,000$ \\
\hline 4. & Biaya Penyusutan Mesin Pabrik & $\mathrm{Rp}$ & $1,667,000$ & $\mathrm{Rp}$ & $20,000,000$ \\
\hline 6 & Biaya PDAM & $\mathrm{Rp}$ & $3,541,667$ & $\mathrm{Rp}$ & $42,500,000$ \\
\hline 5. & Biaya lain-lain & $\mathrm{Rp}$ & $2,000,000$ & $\mathrm{Rp}$ & $24,000,000$ \\
\hline & Total & $\mathbf{R p}$ & $2,718,667$ & $\mathbf{R p}$ & $92,620,000$ \\
\hline
\end{tabular}

Sumber : PT Tirta Mamberamo Sorong, 2015 
Biaya Overhead Pabrik adalah biaya produksi selain biaya bahan baku dan biaya tenaga kerja langsung. Adapun yang termasuk biaya overhead pabrik pada PT Tirta Mamberamo Sorong adalah Biaya tenaga kerja tak langsung, biaya listrik, biaya penyusutan, biaya bahan penolong, biaya air (PDAM) dan biaya lain-lain.

Biaya overhead pabrik tetap sebesar Rp. 64.880.000,- sedangkan biaya overhead pabrik variabel sebesar Rp. 322.000.000,- sehingga total biaya overhead pabrik untuk tahun 2015 adalah sebesar Rp. 386.880.000,-

Biaya overhead pabrik yang dialokasikan pada masing-masing produk berdasarkan persentase pemakaian bahan bahan baku. Dimana biaya bahan baku untuk tahun 2015 untuk ukuran $240 \mathrm{ml}$ sebesar Rp. 6.864.000,- ukuran $600 \mathrm{ml}$ sebesar Rp. 312.000,- dan ukuran gallon 19 liter sebesar 8.424.000,- sehingga total biaya bahan baku sebesar Rp. 15.600.000. Adapun persentase pembebanan

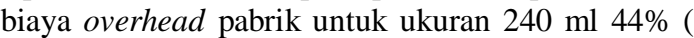
Rp. 6.864.000 : Rp. 15.600.000 ), untuk ukuran 600 ml 2\% (Rp. 312.000 : Rp. 15.600.000 ), dan untuk ukuran gallon 19 liter ( Rp. 8.424..000 : Rp. 15.600.000 ). Biaya overhead pabrik aktual untuk ukuran 240 ml Rp. 172.858.400,- ukuran 600 ml Rp. 7.857.200,- dan ukuran gallon Rp. 212.144.400,-

Berdasarkan rekapitulasi tersebut, dapat dilihat besarnya selisih serta komponen yang menunjukan selisih terbesar untuk biaya bahan baku terlihat selisih merugikan (unfavourable) pada harga bahan baku dan pemakaian bahan baku dikarenakan perusahaan menetapkan jumlah standar biaya bahan baku yang kecil dibandingkan biaya bahan baku aktual yang terjadi. Perusahaan memang menyusun rancangan biaya standar biaya bahan baku tetapi menimbulkan selisih biaya bahan baku yang tak sedikit diakibatkan pemakaian bahan baku yang kurang baik sehingga terjadi pemborosan. Varians yang terjadi dalam biaya bahan baku dapat dijadikan perhatian kerja bagi perusahaan khususnya bagian produksi untuk lebih menghemat bahan baku dan perlu adanya pengendalian dari bagian pembelian untuk memperhatian bahan baku yang akan dibeli sehingga tidak terjadi varians yang merugikan (unfavourable

Rekapitulasi Varians Biaya Produksi PT Tirta Mamberamo Sorong

Periode Januari - Desember

Tahun 2015

\begin{tabular}{|c|c|c|c|c|c|c|c|c|}
\hline & Jenis Varians & & $\begin{array}{c}\operatorname{uran} 240 \\
\mathrm{ml}\end{array}$ & Uku & $\begin{array}{l}\operatorname{ran} 600 \\
\mathrm{ml}\end{array}$ & & $\begin{array}{l}\text { Juran } \\
\text { allon } 19 \\
\text { Liter }\end{array}$ & Ket \\
\hline Biaya be & baku & & & & & & & \\
\hline . & Harga Bahan Baku & $\mathrm{Rp}$ & $1,200,000$ & $\mathrm{Rp}$ & 54,000 & $\mathrm{Rp}$ & 972,000 & RUGI \\
\hline 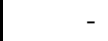 & Efisiensi Pemakaian Bahan B & $\mathrm{Rp}$ & 300,000 & $\mathrm{Rp}$ & 9,000 & $\mathrm{Rp}$ & 285 & RUGI \\
\hline Biaya $\mathbf{T}$ & a Kerja Langsung & & & & & & & \\
\hline . & Biaya Upah TKL & & 0 & & 0 & & 0 & - \\
\hline- & Efisiensi Upah TKL & & 0 & & 0 & & 0 & - \\
\hline Biaya O & ead Pabrik & & & & & & & \\
\hline- & Pengeluaran BOP & $\mathrm{Rp}$ & $2,631,200$ & $\mathrm{Rp}$ & 119,600 & $\mathrm{Rp}$ & $3,229,200$ & RUGI \\
\hline- & Kapasitas BOP & & 0 & & 0 & & 0 & - \\
\hline - & Efisiensi BOP & & 0 & & 0 & & 0 & - \\
\hline
\end{tabular}

\section{KESIMPULAN DAN SARAN}

\section{Kesimpulan}

Berdasarkan hasil pembahasan dan analisa selisih biaya produksi yang telah terjadi pada PT Tirta Mamberamo Sorong, maka dapat ditarik kesimpulan sebagai berikut :
1. Terdapat selisih antara biaya produksi standar dan biaya produksi aktual yang menyebabkan kerugian (unfavourable) biaya produksi pada PT Tirta Mamberamo Sorong

2. Faktor penyebab terjadinya varians biaya produksi adalah karena kesalahan 
perusahaan dalam menerapkan standar biaya produksi dengan baik untuk biaya bahan baku dan biaya overhead pabrik, sedangkan untuk biaya tenaga kerja langsung tidak menunjukan selisih.

\section{Saran}

Berdasarkan kesimpulan diatas serta mengingat betapa pentingnya arti dan peranan biaya standar yang akurat terhadap pangendalian biaya pada PT Tirta Mamberamo Sorong, maka diajukan saran sebagai berikut :

1. Dari selisih-selish yang telah dikemukakan perusahaan hendaknya lebih hati-hati dalam menentukan harga bahan baku. Dalam menentukan standar harga bahan baku hendaknya perusahaan mempertimbangkan segala kemungkinan yang dapat timbul seperti kenaikan harga bahan baku, begitu pula dalam pemakaian bahan baku perusahaan hendaknya melakukan pengawasan terhadap para pekerja dibagian produksi sehingga tidak terjadi penggunaan bahan baku yang berlebihan.

2. Perusahaan hendaknya melaksanakan pengawasan yang lebih intensif dan terarah untuk menghindari penyimpangan dari berbagai standar yang telah ditetapkan. Pengawasan ini dilakukan baik dalam pembelian bahan baku, selama proses produksi berlangsung maupun setelah barang siap untuk dipasarkan.

3. Agar perusahaan dapat berjalan terusmenerus, perusahaan harus memperhitungkan berapa pendapatan yang telah dicapai, karena adanya varians yang merugikan tersebut masih dapat melakukan proses produksi dengan melihat perubahan yang telah terjadi diluar perusahaan seperti harga bahan baku bila dibandingkan dengan standar yang dibuat.

\section{DAFTAR PUSTAKA}

Mahfoed, Mas'ud, 1985, Akuntansi manajemen, bagian penerbit Fakultas Ekonomi Universitas Gadja Madha, Yogyakarta.

Matz, Adolph dan Milton F. Ussry, 1992, Akuntansi Biaya Perencanaan dan Pengendalian, Jilid I, Edisi Kedelapan, Penerbit Erlangga, Jakarta.

Drs. Mulyadi, M.sc., Akuntan, 1986, Akuntansi Biaya Penentuan Harga Pokok dan
3. Selama periode akuntansi berjalan terjadi penyimpangan yang cukup signifikan antara standar dan aktual dan selisih-selisih tersebut sangat merugikan perusahaan pada biaya produksi.

Pengendalian Biaya, Edisi ketiga, Bagian Penerbit Fakultas Ekonomi Universitas Gadja Mada, Yogyakarta.

Drs. Mulyadi, M.sc., Akuntan, 1991, Akuntansi Biaya Edisi 5, Bagian Penerbitan Sekolah Tinggi Ilmu Ekonomi YPKN Universitas Gadja Mada, Yogyakarta

Rony, Helmy, 1990, Akuntatansi Biaya Pengantar untuk perencanaan dan Pengendalian biaya produksi, Lembaga penerbit Fakultas Ekonomi Universitas Indonesia, Jakarta.

Sugiyono, 1994, Metode Penelitian Administrasi , Alfabeta, Bandung.

Drs. R.A. Supriyono, S.U., Akt, 1983, Akuntansi Biaya Pengumpulan Biaya dan Penentuan Harga Pokok., Buku I : Edisi kedua, Bagian Penerbit Fakultas Ekonomi Universitas Gajah Mada, Yogyakarta. 